\title{
MODEL PEMBELAJARAN PROBLEM BASED LEARNING (PBL) TERHADAP KEMAMPUAN BERPIKIR KRITIS MATEMATIKA SISWA KELAS IX
}

\author{
Mauly Dewanty Agustina ${ }^{1)}$, Agustiany Dumeva Putri ${ }^{2)}$, Tria Gustiningsi ${ }^{3)}$ \\ ${ }^{12233)}$ Program Studi Pendidikan Matematika, Fakultas Ilmu Tarbiyah dan Keguruan, Universitas \\ Islam Negeri Raden Fatah Palembang \\ 1)email: maulydewantyagustina@gmail.com \\ ${ }^{2)}$ email: anydumeva@yahoo.co.id \\ ${ }^{3)}$ email: triagustiningsi@yahoo.co.id
}

\begin{abstract}
This research aims to know the influence of Problem Based Learning model on the ability to think critically mathematics students class IX of MTs Aulia Cendekia Palembang. This research is a quantitative research to the type of experimental class. The subjects of this research are, students of class IX.A as experiment class and class IX.B as control class. In the experimental class learning process is taught with Problem Based Learning model. Data collection using test to know ability to think critically mathematics and observation sheet. The analysis of data used t test and significance level of $=0,05$. The results of data analysis using $t_{\text {test }}$ obtained $t_{\text {critical }}>t_{\text {table. }}$. It means that there is influence of Problem Based Learning model on the ability to think critically mathematics students class IX of MTs Aulia Cendekia Palembang.
\end{abstract}

Keywords: Problem Based Learning Model, Critical Thinking

\begin{abstract}
Abstrak
Penelitian ini bertujuan untuk mengetahui bagaimana pengaruh Model Pembelajaran Problem Based Learning terhadap kemampuan berpikir kritis matematika siswa kelas IX di MTs Aulia Cendekia Palembang. Penelitian ini merupakan penelitian kuantitatif dengan jenis penelitian eksperimen. Subjek penelitian ini yaitu, siswa kelas IX.A sebagai kelas eksprimen dan kelas IX.B sebagai kelas kontrol. Pada proses pembelajaran kelas eksperimen diajarkan dengan model pembelajaran Problem Based Learning. Pengambilan data menggunakan tes untuk mengukur kemampuan berpikir kritis matematika dan lembar observasi. Dari hasil analisis data menggunakan uji $\mathrm{t}$ dan taraf signifikan $=0,05$. Hasil analisis data menggunakan uji $t$ diperoleh $t_{\text {hitung }}>t_{\text {tabel. }}$. Hal ini menunjukkan bahwa ada pengaruh Model Pembelajaran Problem Based Learning Terhadap Kemampuan Berpikir Kritis Matematika Siswa Kelas IX di MTs Aulia Cendekia Palembang.
\end{abstract}

Kata Kunci: Model Pembelajaran Problem Based Learning, Berpikir Kritis 


\section{PENDAHULUAN}

Pada tahun 1989, NCTM mengeluarkan The Curriculum and Evaluation Standards for School Mathematics disusun sebagai suatu standar dalam usaha memberi kesempatan pada siswa di seluruh tingkat pendidikan untuk mengonsumsi informasi secara kritis, usaha ini dilakukan berdasarkan fakta bahwa kehidupan masyarakat pada era informasi telah menuntut mereka untuk tidak sekedar mengingat informasi tetapi dituntut juga untuk berpikir kritis, logis, kreatif dan sistematis (Suwarma, 2009). Menurut Permendikbud No 58 tahun 2014, mata pelajaran matematika perlu diberikan kepada semua peserta didik mulai dari sekolah dasar, untuk membekali peserta didik dengan kemampuan berpikir logis, analitis, sistematis, kritis, inovatif dan kreatif serta kemampuan kerja sama.

Berdasarkan uraian di atas, berpikir kritis merupakan bagian yang sangat penting dalam pembelajaran terkhususnya untuk pembelajaran matematika, agar peserta didik dapat mencari, memilih, menerima informasi dengan tepat. Menurut (Wijaya \& Bharata, 2016), kemampuan berpikir kritis merupakan bagian yang sangat penting dalam pembelajaran matematika. Karena kemampuan berpikir kritis adalah kebutuhan bagi siswa untuk mencapai kesuksesan dalam kehidupan khususnya pada pekerjaan di kehidupan nyata. Begitu pula menurut (Mahmuzah, 2015), pada pembelajaran matematika, kemampuan berpikir kritis merupakan komponen penting yang harus dimiliki siswa, karena supaya siswa mampu membuat atau merumuskan, mengidentifikasi, menafsirkan dan merencanakan pemecahan masalah.

Berdasarkan wawancara yang dilakukan peneliti dengan salah seorang guru matematika MTs Aulia Cendekia Palembang bernama Lili Peni Lestari, S.Pd, menyatakan bahwa dalam proses pembelajaran siswa sudah cenderung aktif, namun siswa masih mengalami kesulitan dalam memecahkan permasalahan dalam soal yang tidak rutin yang membutuhkan penalaran dan analisis, karena soal yang tidak rutin membutuhkan pemikiran lebih lanjut dan perlu kemampuan berpikir secara kritis. Berdasarkan hasil tes awal yang dilakukan oleh peneliti kepada 34 siswa kelas IX MTs Aulia Cendekia Palembang, rata-rata kemampuan siswa berpikir kritis matematika masih sangat rendah, yaitu sebesar 24,75. Tes dilakukan dengan menggunakan soal-soal yang mengacu kepada indikator kemampuan berpikir kritis matematika. Dari hasil tes tersebut, ada 2 orang yang memiliki kemampuan berpikir kritis matematika yang tergolong tinggi, 17 orang yang tergolong rendah dan 15 orang yang tergolong sangat rendah. 
Berdasarkan permasalahan yang terjadi hal tersebut menggambarkan kemampuan berpikir kritis siswa yang masih rendah. Salah satu penyebab munculnya permasalahan ini adalah siswa terbiasa menyelesaikan soal rutin yang kurang meningkatkan kemampuan berpikir kritis dalam pembelajaran matematika. Oleh karena itu agar terjadi pembelajaran yang lebih bermakna, upaya yang dapat dilakukan guru dalam mengembangkan kemampuan berpikir kritis yaitu melalui pembelajaran yang memberi siswa kesempatan untuk membangun pengetahuan oleh dirinya sendiri (Susanto, 2014). Agar terjadi pembangunan pengetahuan yang baik dan membuat pembelajaran menjadi lebih bermakna bagi siswa, diperlukan adanya suatu model pembelajaran yang dapat mengkondisikan siswa dalam belajar, membangun pengetahuan, dan melatih kemampuan berpikir kritis.

Salah satu alternatif model pembelajaran yang dapat digunakan yaitu Penerapan Model Pembelajaran Problem Based Learning (PBL) atau pembelajaran berbasis masalah. Menurut (Fathurrohman, 2015), Problem Based Learning (PBL) merupakan pembelajaran yang menggunakan masalah nyata (autentik) yang tidak terstruktur (illstructured) dan bersifat terbuka sebagai konteks bagi peserta didik untuk mengembangkan keterampilan menyelesaikan masalah dan berpikir kritis serta sekaligus membangun pengetahuan baru. Sehingga model pembelajaran Problem Based Learning dapat menjadi solusi untuk melatih kemampuan berpikir kritis siswa dan dapat mengkondisikan siswa dalam belajar kelompok untuk saling berinteraksi.

\section{METODE PENELITIAN}

Penelitian ini digolongkan ke dalam penelitian kuantitatif dengan metode eksperimen dan rancangan True-Experimental Design, menggunakan Posttest-Only Control Design (Sugiyono, 2016). Pada desain ini terdapat dua kelas yang dipilih secara simple random sampling, di mana pada kelas pertama akan diberi perlakuan dengan model pembelajaran Problem Based Learning sebagai kelas eksperimen dan kelas kedua diberikan perlakuan metode pembelajaran ceramah, tanya jawab dan penugasan sebagai kelas kontrol. Masing-masing kelas diberikan perlakuan untuk dua kali pertemuan dan pada pertemuan ketiga diberikan tes akhir (posstest) untuk melihat kemampuan berpikir kritis siswa pada masing-masing kelas setelah diberi perlakuan.

Variabel dalam penelitian ini adalah: (1) model pembelajaran problem based learning $(P B L)(2)$ variable terikat adalah kemampuan berpikir kritis matematika siswa. 
Populasi dalam penelitian ini yaitu kelas IX MTs Aulia Cendekia Palembang yang terdiri dari 3 kelas dengan jumlah 100 orang siswa. Pemilihan sampel menggunakan teknik Simple Random Sampling.

Teknik pengumpulan data yaitu menggunakan tes dan observasi. Tes diberikan untuk mengukur atau mengetahui pengaruh model pembelajaran Problem Based Learning terhadap kemampuan berpikir kritis matematika siswa kelas IX MTs Aulia Cendekia Palembang. Tes dilakukan setelah diterapkannya model pembelajaran Problem Based Learning pada kelas eksperimen. Tes yang dilakukan berupa posttest. Tes yang diberikan sebagai data utama dalam penelitian untuk melihat kemampuan berpikir kritis matematika siswa. Observasi guru dilakukan untuk melihat sistematika pelaksanaan pembelajaran Problem Based Learning yang dilaksanakan oleh guru sesuai dengan langkah pembelajaran sehingga dapat terlihat model pembelajaran Problem Based Learning terlaksana dengan baik atau kurang terlaksana dengan baik.

Adapun teknik analisis data yaitu sebagai berikut: 1) Tes dilihat berdasarkan skor kemampuan berpikir kritis matematika. Soal posttest diukur dari indikator kemampuan berpikir kritis yaitu interpretation, analysis, evaluation, inference, explanation dan self regulation. analisis data tes dalam penelitian ini menggunakan uji normalitas data yang digunakan untuk melihat data normal atau tidak, uji homogenitas data digunakan untuk melihat apakah kedua kelompok tersebut mempunyai varians yang sama atau tidak, jika sama maka homogen dan jika tidak berarti tidak homogen, dan selanjutnya uji hipotesis digunakan untuk melihat hasil akhir data tes yang dierikan kepada siswa. 2) Lembar observasi yaitu data hasil keterlaksanaan pembelajaran untuk memberikan gambaran pelaksanaan pembelajaran.

\section{HASIL DAN PEMBAHASAN}

Dalam penelitian ini, tes digunakan untuk mengetahui kemampuan berpikir kritis siswa yang telah dicapai. Setelah pembelajaran diberikan kepada kelas eksperimen dengan menggunakan model pembelajaran Problem Based Learning dan kelas kontrol dengan menggunakan metode pembelajaran ceramah, tanya jawab dan penugasan. Setelah pembelajaran selesai, diberikan posttest dan diujikan pada kelas eksperimen yang diikuti oleh 34 siswa dan kelas kontrol yang diikuti oleh 34 siswa. Berikut ini adalah hasil posttest siswa kelas eksperimen dan kelas kontrol. 
Tabel 1.Hasil Posttest Siswa Kelas Eksperimen dan Kelas Kontrol

\begin{tabular}{ccccc}
\hline $\begin{array}{c}\text { Kategori Kemampuan } \\
\text { Berpikir Kritis Matematika }\end{array}$ & $\begin{array}{c}\text { Rentang } \\
\text { Nilai }\end{array}$ & $\begin{array}{c}\text { Frekuensi Kelas } \\
\text { Eksperimen }\end{array}$ & $\begin{array}{c}\text { Frekuensi } \\
\text { Kelas Kontrol }\end{array}$ & Persentase \\
\hline Sangat Kritis & $81-100$ & 2 & - & $5,88 \%$ \\
Kritis & $61-80$ & 20 & 15 & $58,82 \%$ \\
Sedang & $41-60$ & 7 & 11 & $20,59 \%$ \\
Rendah & $21-40$ & 5 & 8 & $14,71 \%$ \\
Sangat Rendah & $0-20$ & - & - & - \\
\hline
\end{tabular}

Uji normalitas dalam penelitian ini menggunakan uji Liliefors. Uji normalitas ini dilakukan pada data posttest siswa di kelas Eksperimen dan kelas Kontrol. Data berdistribusi normal apabila $\mathrm{L}_{\text {hitung }}<\mathrm{L}_{\text {tabel. }}$. Berdasarkan analisis data di atas didapatkan nilai $\mathrm{L}_{0}=0,1334<\mathrm{L}_{\mathrm{k}}=0,1519$ maka $\mathrm{H}_{0}$ diterima untuk Kelas Eksperimen dan karena $\mathrm{L}_{0}$ $=0,1439<\mathrm{L}_{\mathrm{k}}=0,1519$ maka $\mathrm{H}_{0}$ diterima untuk Kelas Kontrol. Dapat disimpulkan bahwa data kedua kelas tersebut berdistribusi normal. Pada penelitian ini, uji homogenitas data dilakukan dengan menggunakan uji-F. Berdasarkan perhitungan diperoleh $\mathrm{F}_{\text {hitung }}=1,0451$ dan $\mathrm{F}_{\text {tabel }}=1,7878$. Dengan demikian, $\mathrm{H}_{0}$ diterima karena $\mathrm{F}_{\text {hitung }}<\mathrm{F}_{\text {tabel }}$ yaitu $1,0451<$ 1,7878 dengan $\alpha=0,05$. Maka, hal ini berarti bahwa hasil post-test kelas eksperimen dan kelas kontrol bersifat homogen.

Untuk membuktikan hipotesis yang telah dirumuskan dan untuk mendapat suatu kesimpulan maka hasil data tes akan dianalisis dengan menggunakan uji-t. Pada penelitian ini, dilakukan uji-t terhadap nilai posttest siswa pada kelas eksperimen dan kelas kontrol. Dari perhitungan menggunakan uji-t yang dilakukan dengan taraf signifikan $5 \%$, diperoleh $t_{\text {hitung }}=2,1439$ dengan $\mathrm{dk}=(34+34-2)=66$ dan $t_{\text {tabel }}=1,9966$, karena $t_{\text {hitung }}$ $>\mathrm{t}_{\text {tabel }}$ maka $\mathrm{H}_{0}$ ditolak. Sehingga dapat disimpulkan bahwa ada pengaruh model pembelajaran problem based learning (PBL) terhadap kemampuan berpikir kritis matematika siswa kelas IX di MTs Aulia Cendekia Palembang. Data observasi yang diperoleh dari hasil pengamatan pelaksanaan model pembelajaran problem based learningyang dilaksanakan oleh peneliti sesuai dengan tahapan-tahapan yang sudah ditetapkan oleh observer dari pertemuan pertama dan kedua. Adapun tahapan dari model pembelajaran problem based learningyang diobservasi adalah: 
Tabel 2. Tahapan Model Pembelajaran Problem Based Learning

\begin{tabular}{|c|c|c|}
\hline Tahap & Aspek Yang Diamati & Dilaksanakan \\
\hline \multirow{3}{*}{$\begin{array}{l}\text { Tahap } 1 \\
\text { Orientasi siswa pada } \\
\text { masalah }\end{array}$} & Menjelaskan bahan yang digunakan. & $\sqrt{ }$ \\
\hline & Menyajikan situasi masalah. & $\sqrt{ }$ \\
\hline & $\begin{array}{l}\text { Memotivasi siswa untuk terlibat dalam pemecahan masalah } \\
\text { yang dipilih. }\end{array}$ & $\sqrt{ }$ \\
\hline \multirow{5}{*}{$\begin{array}{l}\text { Tahap } 2 \\
\text { Mengorganisasi siswa } \\
\text { untuk belajar }\end{array}$} & $\begin{array}{l}\text { Mengorganisasikan peserta didik ke dalam kelompok } \\
\text { belajar. }\end{array}$ & $\sqrt{ }$ \\
\hline & Menjelaskan tentang aturan-aturan dalam pembelajaran. & $\sqrt{ }$ \\
\hline & $\begin{array}{l}\text { Menyajikan situasi masalah yang lebih umum yang terdapat } \\
\text { pada LKS. }\end{array}$ & $\sqrt{ }$ \\
\hline & $\begin{array}{l}\text { Membagikan LKS berisi permasalahan yang harus } \\
\text { diselesaikan oleh siswa secara berkelompok. }\end{array}$ & $\sqrt{ }$ \\
\hline & $\begin{array}{l}\text { Menginstruksi masing-masing kelompok untuk } \\
\text { mengerjakan LKS. }\end{array}$ & $\sqrt{ }$ \\
\hline \multirow{3}{*}{$\begin{array}{c}\text { Tahap } 3 \\
\text { Membimbing } \\
\text { penyelidikan kelompok }\end{array}$} & Membimbing siswa untuk memecahkan masalah pada LKS. & $\sqrt{ }$ \\
\hline & $\begin{array}{l}\text { Mendorong dialog atau diskusi antar teman dalam } \\
\text { kelompoknya. }\end{array}$ & $\sqrt{ }$ \\
\hline & $\begin{array}{l}\text { Memonitor setiap kelompok dan apabila ada kelompok } \\
\text { yang mengalami kesulitan guru memberikan penjelasan. }\end{array}$ & $\sqrt{ }$ \\
\hline \multirow{2}{*}{$\begin{array}{l}\text { Tahap } 4 \\
\text { Mengembangkan dan } \\
\text { menyajikan hasil karya }\end{array}$} & $\begin{array}{l}\text { Menginstruksikan beberapa perwakilan dari kelompok } \\
\text { siswa untuk memperesentasikan hasil diskusinya di depan } \\
\text { kelas. }\end{array}$ & $\sqrt{ }$ \\
\hline & Menjelaskan hasil yang diperoleh siswa. & $\sqrt{ }$ \\
\hline $\begin{array}{l}\text { Tahap } 5 \\
\text { Menganalisis dan } \\
\text { mengevaluasi proses } \\
\text { pemecahan masalah }\end{array}$ & $\begin{array}{l}\text { Guru membantu siswa untuk melakukan refleksi atau } \\
\text { evalusi terhadap penyelidikan mereka dan proses-proses } \\
\text { yang mereka gunakan. }\end{array}$ & $\sqrt{ }$ \\
\hline
\end{tabular}

Dari tahapan-tahapan yang diobservasi, tahapan-tahapan model pembelajaran problem based learning tersebut terlaksana di setiap pertemuannya. Sehingga dapat dikatakan bahwa model pembelajaran problem based learning terlaksana dengan baik.

\section{PEMBAHASAN}

Dalam penelitian ini, peneliti mengukur kemampuan berpikir kritis matematika siswa dengan memberikan tes berpikir kritis pada pertemuan terakhir. Menurut (Suwarma, 2009) mengatakan langkah awal untuk mewujudkan lingkungan berpikir kritis pada pembelajaran matematika adalah membangun sikap positif, saling berdiskusi, sikap tidak takut salah, rasa bebas untuk mengekspresiksan ide-ide dan kemampuan berkontribusi terhadap pembelajaran. Oleh karena itu, untuk mewujudkan hal tersebut 
peneliti membentuk kelompok kecil di kelas eksperimen agar siswa dapat mengeksplorasi ide-ide yang dimiliki dengan angggota kelompok, sedangkan untuk kelas kontrol lebih menekankan pada kegiatan saat menjelaskan materi dan contoh soal untuk memunculkan kemampuan berpikir kritis siswa. Hal ini sesuai dengan langkah pembelajaran dengan model problem based learning dimana siswa dihadapkan pada masalah nyata atau masalah yang disimulasikan, diminta untuk mencari informasi atau data dari permasalahan, menyusun model matematika dan menuliskan konsep yang terkait dengan model matematika dan memberikan argumennya yang dilakukan melalui diskusi kelompok, karena melalui kegiatan ini siswa akan bernegoisasi untuk membangun kognitifnya (Arifin, 2015).

Pada saat kegiatan pembelajaran, siswa di kelas eksperimen lebih aktif dalam belajar dan siswa antusias dalam mengerjakan lembar kerja yang disediakan, siswa melakukan percobaan-percobaan menggunakan alat peraga yang disediakan sesuai dengan langkah-langkah yang ada pada LKS. Hal yang terpenting dalam model pembelajaran Problem Based Learning pada penelitian ini adalah saat siswa diberikan permasalahan dalam kegiatan pembelajaran. Pada pertemuan pertama, tujuan pembelajaran yang akan dicapai adalah siswa dapat menemukan rumus luas selimut dan luas permukaan kerucut. Dalam kegiatan ini, siswa diberikan permasalahan untuk menuntun siswa dapat menemukan rumus luas selimut dan luas permukaan kerucut dengan peneliti menampilkan sebuah gambar topi ulang tahun beraneka warna dengan bertanya pada semua siswa, “ jika ada sebuah topi ulang tahun yang hanya terbuat dari kertas karton, supaya topi ulang tahun terlihat menarik akan dilapisi kertas metalik seperti pada gambar, kira-kira cukup tidak kalau kalian memiliki kertas metalik dengan ukuran $23 \mathrm{~cm} \times 32 \mathrm{~cm}$.

Setelah peneliti menyajikan masalah kepada semua siswa, peneliti bertanya kepada siswa, "menurut kalian apa yang perlu kalian lakukan untuk mengetahui apa kertas metalik cukup untuk menutupi permukaan topi ulang tahun?" dan Selanjutnya, Pada pertemuan kedua, tujuan pembelajaran yang akan dicapai adalah siswa dapat menemukan rumus volume kerucut. Dalam kegiatan ini, siswa diberikan permasalahan dengan menampilkan gambar cone ice cream, sembari peneliti bertanya kepada siswa," seandainya ada ice cream di sebuah gelas, dan saya ingin memindahkan ice cream tersebut kedalam 3 cone, kira-kira cukup tidak ice cream nya?". Pada kedua peretemuan tersebut siswa aktif dalam menjawab permasalahan yang diberikan oleh peneliti. Tidak 
hanya pada kegiatan awal pembelajaran, pada LKS pertemuan pertama dan pertemuan kedua juga ditampilkan masalah untuk siswa selesaikan dalam kelompok sesuai instruksi yang diberikan pada LKS dan pada pertemuan kedua di setiap kelompok melakukan sebuah percobaan untuk menemukan rumus volume kerucut dengan menggunakan alat peraga bangun kerucut dan tabung yang terbuat dari karton dan menggunkan beras sebagai isi di dalamnya. Diakhir pada setiap pertemuan siswa akan mempresentasikaan hasil LKS di depan kelas.

Meskipun sama-sama menggunakan LKS, namun pada kelas kontrol tidak diberikan permasalahan di awal kegiatan pembelajaran. Karena pada kelas kontrol peneliti langsung menjelaskan pelajaran, memberi contoh soal dan siswa langsung mengerjakan LKS secara berkelompok hanya saja pada pertemuan kedua pada setiap perwakilan barisan siswa mencoba melakukan penemuan sepeti pada kelas eksperimen untuk menemukan volume kerucut dengan bantuan bangun ruang tabung dan mempresentasikan hasil LKS di depan kelas.

Selain perbedaan dalam proses pembelajaran. Siswa kelas eksperimen maupun siswa kelas kontrol memiliki perbedaan dalam menjawab soal posttest. Pada penelitian ini, siswa diberikan 3 soal untuk diselesaikan yang mengukur enam indikator kemampuan berpikir kritis yaitu (1) interpretation, (2) analysis, (3) evaluation (4) inference, (5) explanation dan (6) self regulation. Pada soal nomor 1, peneliti menampilkan soal tentang luas selimut kerucut dengan menampilkan permasalahan melalui topi ulang tahun. Soal nomor 2 untuk menghitung luas permukaan kerucut dan soal nomor 3 untuk menghitung volume kerucut. Dapat dilihat perbedaan dari perwakilan jawaban siswa berikut ini:

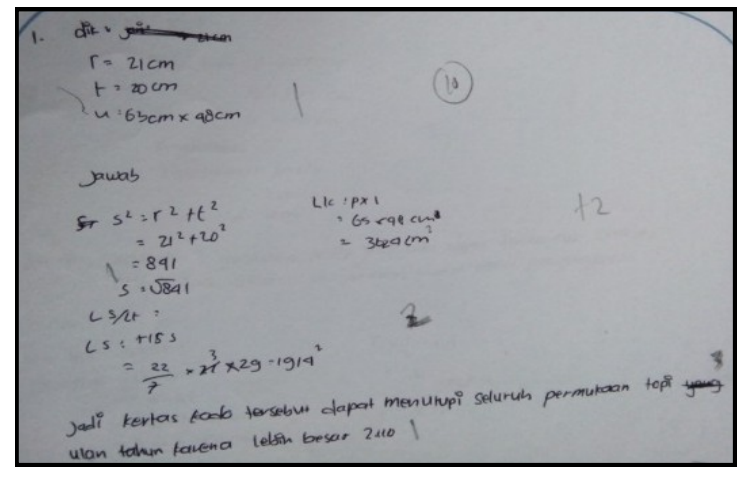

Gambar 1. Jawaban No.1 Kelas Eksperimen

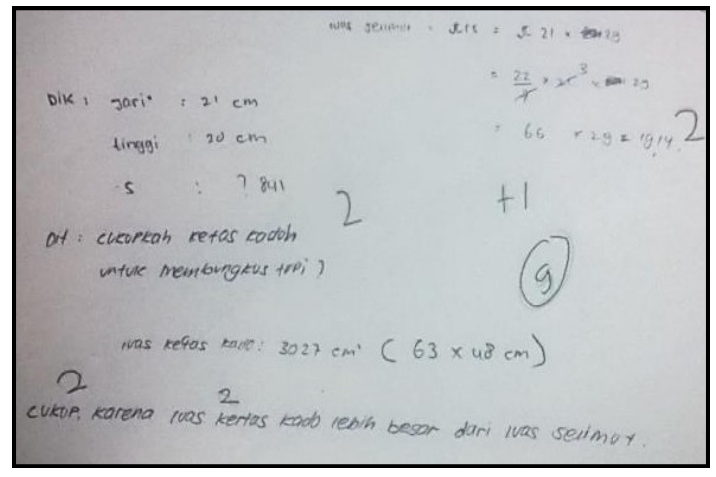

Gambar 2. Jawaban No.1 Kelas Kontrol 
Pada gambar 1 jawaban siswa di atas, indikator interpretation siswa hanya menuliskan apa yang diketahui dari soal. Pada indikator analysis, karena siswa telah mencoba menghubungkan jawaban dengan konsep phytagoras yang pernah ia pelajari sebelumnya untuk mencari ukuran sisi miring dari topi ulang tahun karena yang diketahui dari soal hanya ukuran tinggi topi dan jari-jari topi saja, akan tetapi jawaban siswa tidak diselesaikan hingga akhir. Pada indikator explanation siswa salah menjelaskan kesimpulan yang telah dia tarik. Dan untuk indikator yang terakhir self regulation, karena dari jawaban siswa tidak memenuhi seluruh indikator, hanya 5 indikator yang muncul dan pada beberapa indikator jawaban siswa kurang tepat maka untuk mereview jawaban terlihat bahwa siswa kurang teliti. Sedangkan pada gambar 2 terlihat jawaban siswa belum memenuhi seluruh indikator berpikir kritis yang diinginkan oleh peneliti. Pada jawaban siswa di atas, indikator analysis tidak muncul, karena siswa tidak menghubungkan jawaban dengan konsep phytaghoras yang pernah ia pelajari sebelumnya untuk mencari ukuran sisi miring dari topi ulang tahun karena yang diketahui dari soal hanya ukuran tinggi topi dan jari-jari topi saja, akan tetapi jawaban siswa langsung menghitung luas selimut dan luas kertas kado. Dan untuk indikator yang terakhir self regulation, karena dari jawaban siswa tidak memenuhi seluruh indikator, hanya 4 indikator yang muncul dan pada beberapa indikator jawaban siswa kurang tepat maka untuk mereview jawaban terlihat bahwa siswa tidak teliti. Dari penjelasan di atas, indikator kemampuan berpikir kritis yang diukur menunjukkan bahwa hampir semua indikator tidak tercapai secara maksimal. Selanjutnya untuk soal nomor 2, berikut perwakilan jawaban siswa:

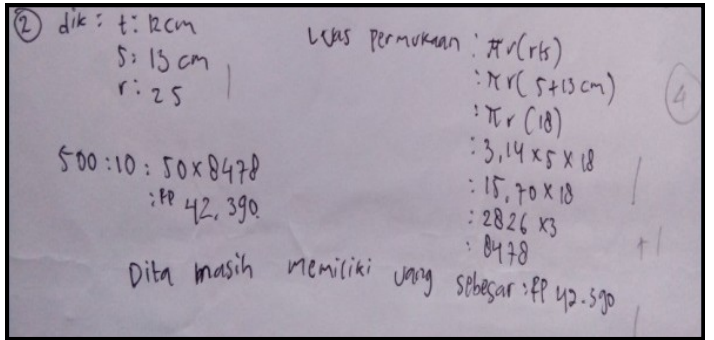

Gambar 3. Jawaban No.2 Kelas Eksperimen

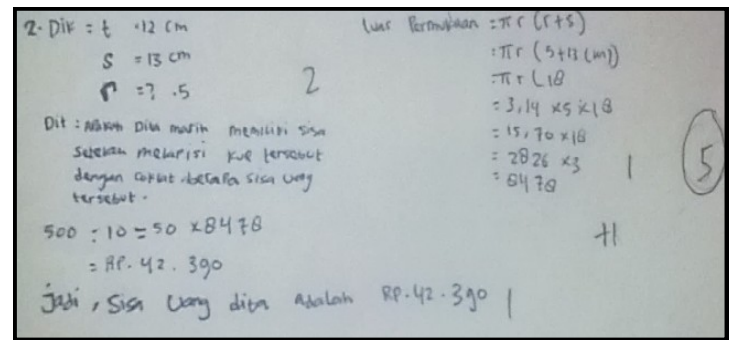

Gambar 4. Jawaban No.2 Kelas Kontrol

Berdasarkan jawaban siswa pada gambar 3, siswa belum memenuhi seluruh indikator berpikir kritis yang di inginkan oleh peneliti. Dua indikator yang tidak muncul yaitu analysis dan explanation. Pada indikator interpretation siswa telah menuliskan apa 
yang diketahui dari soal namun kurang tepat dan siswa tidak menuliskan apa yang ditanyakan dari soal. Pada indikator analysis, dapat dilihat siswa tidak menuliskan jawaban yang menghubungkan dengan konsep phytagoras yang pernah ia pelajari sebelumnya untuk mencari ukuran jari-jari dari kue yang ada karena yang diketahui dari soal hanya ukuran tinggi kue dan ukuran sisi miring kue saja. Pada indikator evaluation siswa tidak menyelesaikan jawabannya dengan tepat, siswa hanya mencari luas permukaan kue saja dengan hasil yang salah dan tanpa melanjutkan langkah selanjutnya. Pada indikator explanation, siswa tidak menuliskan penjelasan dari kesimpulan yang dituliskan. Dan untuk indikator yang terakhir self regulation, karena dari jawaban siswa tidak memenuhi seluruh indikator, hanya 3 indikator yang muncul dan pada beberapa indikator jawaban siswa kurang tepat maka untuk mereview jawaban terlihat bahwa siswa tidak teliti.

Pada gambar 4, siswa belum memenuhi seluruh indikator berpikir kritis yang di inginkan oleh peneliti. Dua indikator yang tidak muncul yaitu analysis dan explanation. Pada indikator analysis, dapat dilihat siswa tidak menuliskan jawaban yang menghubungkan dengan konsep phytagoras yang pernah ia pelajari sebelumnya untuk mencari ukuran jari-jari dari kue yang ada karena yang diketahui dari soal hanya ukuran tinggi kue dan ukuran sisi miring kue saja. Pada indikator evaluation siswa tidak menyelesaikan jawabannya dengan tepat, siswa hanya mencari luas permukaan kue saja dengan hasil yang salah dan tanpa melanjutkan langkah selanjutnya. Pada indikator explanation, siswa tidak menuliskan penjelasan dari kesimpulan yang dituliskan. Dan untuk indikator yang terakhir self regulation, karena dari jawaban siswa tidak memenuhi seluruh indikator, hanya 3 indikator yang muncul dan pada beberapa indikator jawaban siswa kurang tepat maka untuk mereview jawaban terlihat bahwa siswa tidak teliti.

Selanjutnya untuk soal nomor 3, berikut perwakilan jawaban siswa:

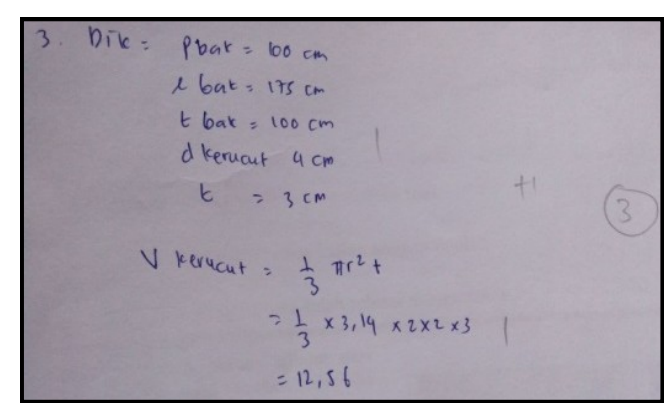

Gambar 5. Jawaban No.3 Kelas Eksperimen

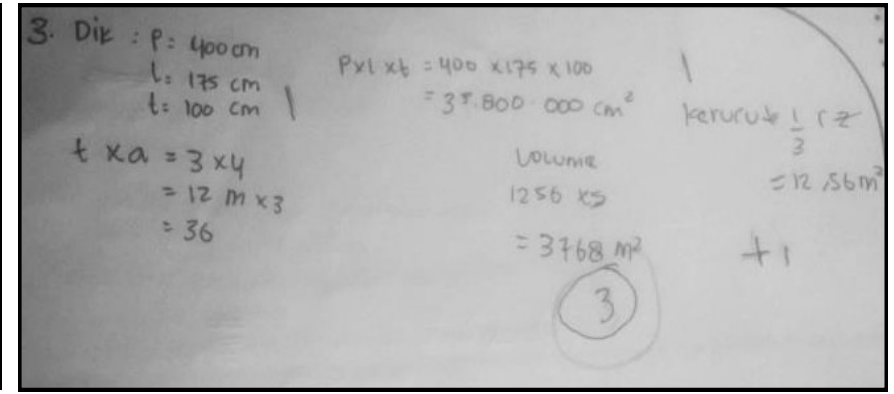

Gambar 6. Jawaban No.3 Kelas Kontrol 
Berdasarkan jawaban siswa pada gambar 5, siswa belum memenuhi seluruh indikator berpikir kritis yang di inginkan oleh peneliti. Pada indikator interpretation, siswa tidak menuliskan apa yang ditanyakan oleh soal. Pada indikator analysis, dapat dilihat siswa tidak menuliskan jawaban yang menghubungkan dengan volume balok. Pada indikator evaluation, siswa menuliskan jawaban dimana seharusnya siswa menghitung volume gundukan pasir yang ada, namun siswa tidak menghitung volume pasir secara keseluruhan. Pada indikator inference dan explanation, siswa tidak menuliskan jawaban. Dan untuk indikator yang terakhir self regulation, karena dari jawaban siswa tidak memenuhi seluruh indikator, hanya 2 indikator yang muncul dan pada 2 indikator tersebut jawaban siswa kurang tepat maka untuk mereview jawaban terlihat bahwa siswa tidak teliti. Pada gambar 6, siswa juga belum memenuhi seluruh indikator berpikir kritis yang di inginkan oleh peneliti.

Pada indikator interpretation, siswa tidak menuliskan apa yang diketahui oleh soal dengan lengkap dan siswa tidak menuliskan apa yang ditanyakan oleh soal. Pada indikator analysis, dapat dilihat siswa telah menuliskan jawaban yang menghubungkan dengan volume balok, tetapi jawaban siswa salah. Pada indikator evaluation, siswa tidak menuliskan jawaban dimana seharusnya siswa menghitung volume gundukan pasir yang ada. Pada indikator inference, karena siswa tidak menyelesaikan penyelesaian jawaban, menyebabkan siswa tidak dapat menarik kesimpulan dari apa yang ditanyakan oleh soal dan indikator explanation siswa tidak bisa menjelaskan kesimpulan karena siswa tidak menarik kesimpulan. Dan untuk indikator yang terakhir self regulation, karena dari jawaban siswa tidak memenuhi seluruh indikator, hanya 2 indikator yang muncul dan pada beberapa indikator jawaban siswa kurang tepat maka untuk mereview jawaban terlihat bahwa siswa tidak teliti.

Perolehan rata-rata nilai posttest siswa di kelas eksperimen 62,26 dan kelas kontrol 53,77 . Berdasarkan rata-rata nilai posttest tersebut, terlihat bahwa rata-rata nilai posttest tidak signifikan karena perbedaan rata-rata tersebut tidak terlalu jauh. Hal ini dikarenakan oleh penerapan model pembelajaran Problem Based Learning di kelas eksperimen dan rata-rata kemampuan berpikir kritis matematika yang diajarkan dengan menggunakanmodel pembelajaran Problem Based Learning dapat memperoleh hasil lebih tinggi dan berpengaruh, jika dibandingkan dengan kelas kontrol yang menggunakan metode pembelajaran ceramah, tanya jawab dan penugasan. Berdasarkan observasi keterlaksanaanmodel pembelajaran Problem Based Learning, setiap langkah-langkah 
model pembelajaran Problem Based Learning terpenuhi dengan nilai akhir 100\% disetiap pertemuan. Maka dapat disimpulkan bahwa model pembelajaran Problem Based Learning terlaksana dengan kategori sangat baik pada setiap pertemuan, sehingga dapat membuat kemampuan berpikir kritis matematika siswa dikelas eksperimen lebih baik dibandingkan dengan kelas kontrol. Namun perbedaan nilai rata-rata antara kelas eksperimen dan kelas kontrol berbanding sedikit, hal ini dikarenakan di sekolah tersebut baru pertama kali diterapkan model pembelajaran Problem Based Learning, sehingga siswa belum terbiasa belajar dengan model pembelajaran selain ceramah.

Dalam pelaksanaanya, penelitian ini memiliki kekurangan yaitu: 1) pelaksanaan pembelajaran pada penelitian ini hanya dua pertemuan, hal ini terjadi karena keterbatasan penelitian yang di laksanakan di kelas IX yang sedang mengejar materi untuk persiapan ujian nasional. Selain itu untuk mengembangkan kemampuan berpikir kritis siswa yang benar-benar optimal dibutuhkan waktu yang kontinu. 2) kurang tepatnya pendesainan LKS dan materi agar tujuan pembelajaran pada setiap pertemuan tercapai dengan waktu yang ada. Namun, kekurangan dalam penelitian ini tidak sepenuhnya menyebabkan penelitian ini tidak berhasil. Meskipun rata-rata nilai posttest kelas eksperimen dan kelas kontrol tidak signifikan, akan tetapi dari rata-rata nilai posttest kelas eksperimen lebih besar dibandingkan rata-rata nilai posttest kelas kontrol. Hal ini terlihat bahwa ada pengaruh Model Pembelajaran Problem Based Learning terhadap Kemampuan Berpikir Kritis Matematika Siswa Kelas IX di MTs Aulia Cendekia Palembang.

\section{SIMPULAN}

Berdasarkan hasil penelitian yang telah peneliti lakukan di kelas IX MTs Aulia Cendekia Palembang dengan materi luas selimut dan permukaan kerucut dan volume kerucut selama 3 kali pertemuan. Menunjukkan hasil perhitungan menggunakan uji-t yang dilakukan pada siswa dengan taraf signifikan $5 \%$, diperoleh $t_{\text {hitung }}>t_{\text {tabel }}$ maka $\mathrm{H}_{0}$ ditolak. Jadi, disimpulkan bahwa ada pengaruh Model Pembelajaran Problem Based Learning terhadap Kemampuan Berpikir Kritis Matematika Siswa Kelas IXdi MTs Aulia Cendekia Palembang. 


\section{DAFTAR PUSTAKA}

Arifin, S. (2015). Implementasi Pembelajaran Berbasis Masalah untuk Meningkatkan Soft Skills Mahasiswa Pendidikan Matematika UIN Raden Fatah Palembang. Jurnal Pendidikan Matematika RAFA , 1 (1), 63-76.

Fathurrohman, M. (2015). Paradigma Pembelajaran Kurikulum 2013 Strategi Alternatif Pembelajaran di Era Global. Yogyakarta: Kalimedia.

Mahmuzah, R. (2015). Peningkatan Kemampuan Berpikir Kritis Matematis Siswa SMP Melalui Pendekatan Problem Posing. Jurnal Peluang , 4 (1), 64-72.

Sugiyono, S. (2016). Metode Penelitian Kuantitatif dan Kulaitatif dan R\&D. Jakarta: Alfabeta.

Susanto, A. (2014). Teori Belajar \& Pembelajaran di Sekolah Dasar. Jakarta: Kencana Premedia Group.

Suwarma, D. M. (2009). Suatu Alternatif Pembelajaran Kemampuan Berpikir Kritis Matematika. Jakarta: Cakrawala Maha Karya.

Wijaya, N. M., \& Bharata, H. (2016). Pengembangan Kemampuan Berpikir Kritis Matematis Siswa Melalui Strategi Pembelajaran Thinking Aload Pair Problem Solving. Konferensi Nasional Penelitian Matematika dan Pembelajarannya (KNOMO I) (pp. 201-215). Surakarta: Universitas Muhammadiyah Surakarta. 